\title{
Moral and Intellectual Responsibilities of a Criminal Law Expert in Giving Information in the Court
}

\author{
Alfitra \\ State Islamic University Syarif Hidayatullah \\ Jakarta, Indonesia \\ alfitra@uinjkt.ac.id
}

\begin{abstract}
The information given by an expert at a court hearing is needed by the judge to convince him. Therefore, at the inspection in the court session for the judge, the role of the expert statement is very important and must be carried out for the sake of justice. However, the judge is thus not obliged to obey the opinion of the expert if the opinion of the expert is contrary to his beliefs. Regarding the expert's statement, it is stated in Article 180 paragraph (1) of the Criminal Procedure Code that in matters needed to clear up the problems arising in court hearings the chairperson of the hearing can ask for expert information and can also request that new material be submitted by interested parties. Article 7 paragraph (1) letter $h$ also states that the investigator has an obligation that is to bring in the experts needed in connection with the case examination. For example, in cases where the accused is suspected of having a mental disorder or in other cases that do require the role of an expert. Therefore, it can be seen that information from an expert has an important role in the process of examining criminal cases in court. information from someone who has expertise in a criminal offense that cannot be made alone by a judge or investigator because, in essence, the statement from the expert will make litigation of a criminal case for examination based on his expertise which may enable a decision to be made. But if there is an error in assessing the evidence, it will result in errors in the decision by the court judge.
\end{abstract}

Keywords: moral, expert, intellectual

\section{INTRODUCTION}

The law of proof is one of the oldest legal fields. This is because humans and society are just as primitive. They have a sense of justice, where a sense of justice will be touched if there is a judge's decision to punish an innocent person, or release a guilty person, or win an unauthorized person in a dispute. In order not to be decided wrongly like that, the evidence is needed in the judicial process. So in the history of law, a set of laws and rules has developed in the field of proof from an irrational and complex system. Regarding Verification and the Law of Proof in the Criminal Procedure Law When viewed from the evidentiary law that we adhere to now / proof system can be limited as roundness or the whole range of provisions concerning evidentiary activities that are interconnected with one another that are inseparable and become a whole unit. The contents of the proof system are mainly about what evidence can be used to prove, how the evidence can be used, and the strength of the evidence and standards/criteria that are

\author{
Fitriyani Zein \\ State Islamic University Syarif Hidayatullah \\ Jakarta, Indonesia \\ fitriyani.zein@uinjkt.ac.id
}

measures in concluding proven objects (objects). As understood so far, the proof system is a provision on how to prove and support in concluding what is proven.

People who can provide information about the interests of the investigation, prosecution, and trial of a criminal case that he heard, he saw himself and he experienced himself. The testimony of the Witness is one of the shreds of evidence in a criminal case in the form of a statement from a witness concerning a criminal event which he heard by himself, he saw for himself and experienced by himself by mentioning his reasons and knowledge. From the above, there is a clear difference between Witnesses and Experts. The witness gave information based on something he heard himself, he saw for himself and he experienced it himself, but he cannot conclude it while the expert gave his information based on his special expertise and can conclude it.

Thus the use of the term statement of the Expert in criminal cases is an incorrect term. Because the Witness is different from the Expert, the Expert is not a legal subject who has the right to receive protection as stipulated in Law No. 13 of 2006 which has been amended by Law No. 31 of 2014, concerning the Protection of Witnesses and Victims, even though the Expert should have the right to obtain legal protection as well as the protection given to the Witness. Based on the prevailing laws and regulations, it is affirmed that both the Expert Information and the Witness's Statement in a criminal case are valid evidence, therefore legal protection as given to the Witness should be given to the Expert. Legal protection given to the Expert is only briefly mentioned in Article 9 paragraph (1) letter (d) of Law No. 28 of 1999 concerning the Implementation of a Clean and Free Collusion Corruption Country (KKN), namely the participation of the community in realizing a clean state organizer obtaining legal protection rights in the case of being asked to attend investigations, investigations, and court hearings, witnesses ; and expert witnesses, in accordance with the provisions of the applicable legislation.

Regarding the issue of protection against the Expert also regulated in the 2003 United Nations Anti-Corruption Convention which has been ratified in Law No. 7 of 2006 concerning Ratification of the United Nations Convention Against Corruption, 2003 (United Nations Anti-Corruption Convention, 2003). 
In Article 32 paragraph (1) the Convention states that Every State Party must take appropriate actions in accordance with its national legal system and in its authority to provide effective protection from possible retaliation or intimidation for witnesses and experts who testify about crimes established in accordance with this Convention and, as appropriate, for their families and other people close to them.

Expert Payment Before answering whether the Expert who was questioned in a criminal case both in the investigation, investigation and court proceedings has the right to get a payment or not, then what is the right and obligation of an Expert is first described based on the applicable legislation. Obligations of Experts are as follows:

First, Article 179 paragraph (1) of Law No. 8 of 1981 states that "everyone who is asked for his opinion as a judicial medical expert or doctor or another expert must provide expert information for justice". Second, Article 160 paragraph (4) Law No. 8 of 1981 states that "If the court considers it necessary, a witness or expert must swear or promise after the witness or expert has finished giving information". While the expert's right is to get legal protection as mentioned above. Besides, an Expert has the rights as stated in Article 229 (1) of the Criminal Procedure Code, namely that:

"Witnesses or experts who have attended fulfilling the call in order to provide information at all levels of examination, have the right to receive reimbursement according to the applicable laws and regulations," then in Article 229 paragraph (2) it is stated that "Officials who call must notify witnesses or experts regarding their rights as referred to in paragraph (1) ". Based on the article it is clearly stated that the Expert has the right to get payment. Becoming an Expert when the Inquisitor / Investigation stage and in Aqusatoir / Court in every criminal case has the right to get payment, but regarding how much amount to be paid to the Expert no legislation regulates it.

\section{METHOD}

This research uses a normative juridical approach and empirical jurisdiction that uses primary data and secondary data. Primary data is obtained through field studies. Secondary data is obtained through literature. Data analysis is done through qualitative analysis. The results of the study explained that the function of expert testimony as evidence of crimes in the criminal justice process is needed starting from the process of examining cases, both at the investigation examination stage and the examination of court proceedings a crime case. Very complex, specific complex. Expert assistance has been needed since the beginning of the investigation by investigators, public prosecutors, and judges at the time of examination of cases in court proceedings. Expert information is legal evidence according to law. Expert information on article 1 point 28 of the Criminal Procedure Code, expert information is information given by a person who has special expertise about the things needed to make litigation of a criminal case for examination.
The technique of data collection used in this research is in the form of literature studies and field studies. Literature studies are used to collect and analyze legal materials, both primary legal material, and secondary legal material. While field studies are used to collect data in the form of opinions from the parties concerned. Field studies conducted utilizing interviews are a question and answer process in research that takes place verbally in which two people or more face to face listen directly to information or information. Interviews are openly open by using a tool in the form of a list of prepared questions (as an interview guide) according to the problems that the answers will be sought without closing the possibility to add other spontaneous questions in connection with the answers given by the respondent.

\section{RESULTS}

Based on the research conducted by the team at several District Courts in the Jakarta, Bekasi, Tangerang, and Bekasi (Jabodetabek) areas, both directly saw the session time and asked directly to the legal experts concerned. There were several findings that sometimes the expert's statement is evidence that following article 184 of the Criminal Procedure Code, it can also be a consideration of the judge, in deciding the defendant.

Examples of cases that require expert information are either general crimes or special crimes such as corruption. The Role of the Proof of expert Information in Handling Corruption Crime Cases that an expert provides information, not about all things that are seen, heard and experienced by themselves, but concerning matters that become or in the field of expertise that is related to the case that is being examined by a judge.

Expert information is an appreciation and reality and/or conclusion for the award based on his expertise. If the expert's information is given at the level of investigation, before giving information, the expert must take an oath or promise first, regulated in article 179 paragraph (2) KUHAP. Another example is the case of hearing expert testimony in a court hearing, which is a case related to press offenses. Law Enforcement Apparatus Requested to Refer to SEMA No. 13 of 2008 it is said that given the many cases of press offenses entering the court, the Supreme Court ("MA") advised the judges to seek information from experts in the press. In handling / examining cases related to press offenses, the assembly should hear/ask for information from expert witnesses from the Press Council, because they are the ones who know the ins and outs of the press in theory and practice. What caught the public's attention was the case of Jessica Wongso, who was famous for cyanide coffee, where her family was Mirna. Where in this case both Prosecutors and Legal Advisers bring in experts both domestic and foreign. and also the case of the presidential election in 2019 at the constitutional court, which also brought experts both in the field of criminal law, the state, and electronic transaction information (ITE). 
Furthermore, it was said that the Criminal Procedure Code does not mention clear criteria about who is an expert. With the increasingly rapid development of technology, there is no limit to the amount of expertise that can provide information so that the disclosure of cases will become brighter, especially concerning criminal acts. An expert generally has special expertise in his field both formal and informal because it does not need to be determined by the existence of formal education, as long as it has been recognized about his expertise. The judge determines that person as an expert or not through his legal considerations. Information of the expert has a vision of what is explained must be about everything that falls within the scope of his expertise which is explained about his expertise that is closely related to the criminal case being examined.

\section{DISCUSSION}

As explained above, it can be seen that for the existence of legal certainty the Government makes clear rules regarding the amount of payment that can be received by the Expert in providing information at the stage of the investigation, investigation, and trial at the Court. The absence of applicable laws and regulations governing who is obliged to pay for the Expert, but as reference material for the formation of regulations governing this matter can be seen from the regulations in the realm of civil law. In Article 49 paragraph (1-2) Law, No. 30 of 1999 concerning Arbitration and Alternative Dispute Resolution states that at the Arbitrator's order or Arbitral Tribunal or the request of the parties one or more Witnesses can be called, or an Expert Witness or more, to hear his statement. The cost of summoning and traveling witnesses or expert witnesses is borne by the requesting party. From the article, it is clear that the obligation to pay for the Expert is borne by the requesting party.

The arrangement of this is because basically, the party requesting the Expert is the party whose position may be stronger. This may be applied in criminal cases, where the Investigator, Public Prosecutor or Suspect or Defendant can bring Experts with the interest to strengthen demands or charges or defense from them and of course the payment obligation is borne by the party that brings it, because by bringing in the Expert at least help the position of the party that brings in the Expert. The problem is that not all suspects or defendants have sufficient economic capacity to pay for the Experts they bring so that due to the economic inability of the suspects or defendants they do not get information from Experts who might strengthen their position. This is what needs to be regulated so that no party feels disadvantaged. Provisions in Article 16 paragraph (1-3) of the Supreme Court Regulation No. 01 of 2008 concerning Procedure for Mediation in Courts we can refer to enriching material for the formation of regulations concerning whom the obligation to pay Experts is charged.
In the PERMA it is said that (1) With the consent of the parties or attorneys, the mediator can invite one or more experts in a particular field to provide explanations or considerations that can help resolve differences of opinion between the parties. (2) The parties must first reach an agreement on the binding or non-binding strength of the explanation and/or judgment of an expert. (3) All costs for the benefit of an expert or more in the mediation process are borne by the parties based on the agreement. From the provision it is clear that the summoning costs are borne by the parties based on the agreement, but this provision will be very difficult to implement in criminal cases, this is due to the position between the suspect/defendant and the investigator/prosecutor in an unbalanced position so that an agreement will be very difficult among them.

Due to the absence of regulations regarding who is obliged to pay Experts, it is necessary to find the right formulation of regulations that accommodates interested parties, especially the interests of economically weak suspects/defendants. Although regulations are an important part of strengthening the role of the Expert, morally there is a large responsibility from an Expert. As part of the intellectual community, an expert needs to erode the reluctance of giving knowledge to the community and still have empathy with fellow humans and live in harmony with each other. This is to anticipate Durkheim's opinion that in increasingly modern society, the individual's sense will increase, and the sense of awareness of the group will be lower. As Geery Spence said "... without noble character, legal (intellectual) experts will only be monsters rather than helper angels.

The law of proof in our criminal procedural law since the entry into force of the HerzieneIndonesischReglement (H.I.R) first and now the KUHAP is to consistently follow this system. Article 294 paragraph (1) of the (H.I.R) formulates that: "no one may be subject to punishment, other than if the judge gets the conviction with legal evidence, that the act has been allowed to be punished and that the accused person is wrong about the act." 5 In essence, the proof system in Article 294 HIR was adopted by refining it into Article 183 of the Criminal Procedure Code whose formulation is: "The judge may not impose a sentence on a person except if with at least two valid shreds of evidence he obtains the conviction that a criminal act actually occurred and that the defendant is guilty of doing so ".

The formulation of Article 183 of the Criminal Procedure Code can be judged to be more perfect because it has set a firmer limit for the judge. attempts to prove the defendant's fault for imposing a criminal sentence. More assertive because the minimum limit of proof is determined, that is, it must use at least two valid evidence from those mentioned in the constitution. Whereas in Article 294-paragraph (2) H.I.R requirements at least with (two) evidence as in Article 183 of the Criminal Procedure Code is not explicitly mentioned. 
This indicates that the negative verification system in the Criminal Procedure Code is better and more guarantees legal certainty. Even though Article 294 paragraph (1) of the HIR does not expressly determine at least two shreds of evidence to be used by judges, the soul of the provisions that one evidence cannot use is also reflected in Article 308 HIR, that the defendant only acknowledges without other supporting facts in the hearing, not enough to be used as evidence. The supporting facts obtained in the trial are of course obtained from evidence other than recognition.

In the system according to the law in a limited manner or also referred to as the system of laws negatively as the point, which is formulated in Article 183, the main points can be concluded, namely: a. The ultimate goal of proof is to decide on a criminal case, which is fulfilling the evidentiary conditions that can impose a crime; b. Standards/conditions regarding the results of evidence to impose criminal charges. The judge's belief in the scope of evidentiary activities can be accepted if the evidentiary activities are not thought of and are seen solely as work to prove it, but to prove to achieve the ultimate goal of criminal case resolution, namely to draw a verdict by the judge.

The mean is, enticing confidence is a part of the process to conclude whether or not a crime has been charged by the public prosecutor. Continuing to conclude the beliefs of the defendant or not the defendant did it, and then conclude the conviction about the defendant's guilt or not in that matter. After all, according to the system of verification according to the Law negatively (limited negativity), the judge may not declare something proven if it is not accompanied by convictions about what the proven object is in case three levels of conviction. That is, the legal facts of at least two shreds of evidence in the trial must not conclude as proven, if the conclusion is not through subjective judgments of the judge, first, the name of the conviction.

Therefore, regarding the matter of the judge's belief in the evidentiary system that we adhere to as Article 183 paragraph (1) do not think about it and be seen as a proof of something, because if it is seen as such, then the belief may be considered no longer within the scope of evidence, but it is included in the scope of punishment specifically as the conditions for imposing a criminal sentence. Regarding the types of evidence that can be used and the strength of evidence and how the evidence is used to prove it in a court session, it is the most important thing in the negative evidence verification law. The three main points have been stated in the articles in the fourth section of the Criminal Procedure Code.

Regarding the types of evidence contained in Article 184. Whereas on how to use evidence and the power of proof of evidence contained in Article 185 189 KUHAP. Regarding the types of evidence that are valid and may be used to prove that has been determined in Article 184 paragraph (1) of the Criminal Procedure Code, are:
1) witness information;

2) expert information;

3) letter;

4) instructions

5) statement of the defendant;

When compared with the evidence in Article 295 HIR, the evidence in Article 184 paragraph (1) of the Criminal Procedure Code is different. The difference is Proof of recognition according to the HIR, which in the expanded Criminal Procedure Code becomes the statement of the defendant. The definition of the defendant's information is broader than just confession. In the Criminal Procedure Code added, new evidence used in H.I.R is not evidence, namely expert testimony. Studied from the perspective of the criminal justice system in general and criminal procedural law (formeelstrafrecht / strafprocesrecht) in particular the "proof" aspect plays a decisive role in declaring someone's fault so that the judge is convicted of a crime.

When viewed from the vision, it is in a juridical framework, the "proof" aspect is unique because it can be classified, both in the criminal / formal criminal law and material criminal law groups. I studied more deeply why there are a polarization of thought "proof" aspects categorized into material criminal law because it is influenced by the existence of an approach from civil law where the "proof" aspect is included in the material categorization of civil law and formal civil law (civil procedural law). However, since the enactment of Law Number 8 of 1981 concerning the Law, the "proof" aspect appears to be regulated in the provisions of formal criminal law. If reviewed in general, "proof" comes from the word "proof" which means a thing (event and so on) that is sufficient to show the truth of a thing (the event).

Article 186 of the Criminal Procedure Code states that the expert's statement is what an expert declares in front of the procurement session, a statement from a new expert has proof value, if the expert before the judge must swear before giving a statement, as stipulated in article 179 paragraph 2, all provisions above for witnesses to also apply as those who provide expert information, provided that they make an oath or promise to provide the best possible information and the truth according to knowledge in their field of expertise. By swearing, an expert has value as evidence if an expert cannot be present.

If an expert is unable to attend and has previously made an oath before the investigator, then the value is the same as the expert's statement before the court, if the expert's statement is given without being sworn because of the following: because he has been held, and still does not want to be sworn or not present and when the examination in front of the investigator is not sworn first. Therefore, the expert's statement is only to strengthen the judge's belief. Thus, as an expert, he has an obligation: to come to court to provide information, 
to take an oath and to provide information according to his expertise.

What is explained by an expert is the conclusions of a condition that is known according to his expertise. Or in other words, is an assessment or appreciation of a situation. This is different from witness statements that are prohibited from giving conclusions. Where the witness is only a re-disclosure of facts that the witness heard, saw, and experienced himself. More clearly stated in article 185 paragraph 5 of the Criminal Procedure Code, both the opinions and imaginations obtained from the thoughts are not witnessed statements.

The strength of expert evidence is free, this does not bind a judge to use it if it is contrary to his beliefs. For expert information in court, it is a tool for judges to find out the truth, and judges are free to use their own opinions or not. What if following other facts in the trial, expert testimony is taken as the opinion of the judge himself. If the information is contradictory, it could be ruled out by the judge, but what needs to be remembered is if the expert's information is ruled out, it must be based on clear reasons, cannot just leave aside without reason. This is because the judge still has the authority to request re-research if it is deemed necessary.

Proving is the same as giving (showing) proof, doing something as truth, carrying out, signifying, witnessing, and convincing. Whereas if examined from the meaning of the lexicon, "proof" is a process, method, action proves, the business shows the right or wrong of the defendant in the court session. Whereas if it is examined from a juridical perspective, according to M. YahyaHarahap, "proof" is the provisions that contain a line and guidelines on ways that the law justifies proving the mistake that was indicted against the defendant. Proof is also a provision that regulates the evidence that is justified by law and regulates evidence that may be used by judges to prove the defendant's fault.

The court may not be as pleasing and arbitrary as it proves the defendant's fault. The aspect of "proof" has begun at the stage of a criminal investigation. In the investigation phase, the investigator's actions to find and find an event that is suspected of being a criminal act to be investigated or not can be carried out. Here, there is already a verification stage. it makes the light of the crime that occurred and to find the suspect. Therefore, with the provisions of Article 1 point 2 and number 5 of the Criminal Procedure Code, investigations and prosecutions and examinations can be carried out in court proceedings, investigations and investigations begin so that from the initial stage evidence and evidence are needed. Concretely, "proof" starts from an investigation and ends until there is a criminal conviction (verdict) by the judge before a court session, both at the district court level and. the high court if the case is carried out by an appeal (apple/revision).

The process of "proof" of its essence is indeed more dominant in the court session to find material truths for events that occur and give confidence to the judge about the incident so that the judge can give the decision as fairly as possible. In this process of proof, there are correlations and interactions regarding what the judge will apply in finding material truth through the stages of proof, evidence and the process of proof of the following aspects:

1) Which actions can be considered proven.

2) Has it been proven that the defendant is guilty of the actions that were indicted against him.

3) What is done regarding the act of doing it?

4) What punishment should be imposed on the accused?. The nature and dimensions of "proof" besides being court-oriented can also be useful and important, both for everyday life and the interests of research institutions where the specificity of the role of proof for the court has the following characteristics:

a) Relating to reality has meaning in the field of criminal law, among others, whether the behavior and matters that occur are fulfilling the qualifications of criminal acts or not.

b) In connection with the reality that can be a criminal case, among others, whether the victim is harmed and whether the condition is made by humans or not nature.

c) Organized through criminal procedural law, among other things, it is determined that the authority to examine facts must be carried out by the police, prosecutors, judges, and other officers according to the procedures stipulated in the law. Regarding the correlation described in the above context, the evidentiary activity is the interaction between the examination carried out by the panel of judges in handling the case, assisted by a substitute clerk, then the public prosecutor who prosecuted and the defendant and his legal counsel.

The three components interact with each other in doing verification, except that the segments and degrees of evidence carried out are slightly different, in the panel of judges through activities examining cases conducting verification activities by examining facts and at the same time assessing the facts revealed by the trial and finally declaring the defendant's mistake or error. in the verdict. Both the public prosecutor and the defendant or legal counsel carry out verification activities as well. It's just that the prosecutor's perspective proves the involvement and error of the defendant in committing a crime, but from the defendant's perspective or legal counsel is inversely proportional to what is done by the public prosecutor. If analyzed, why can these different interpretations and points of view occur, even though the cases and facts faced are the same? This aspect depends on the attitude, starting point, and views of the parties in criminal cases, namely: 
1) The defendant's / legal counsel's view of the accused as subjective views and subjective positions;

2) The view of the public prosecutor is a subjective view of an objective position;

3) The judge's view is expressed as an objective view from the objective side as well.

With the benchmarks mentioned above, although somewhat in line with the above views, according to AchmadSoemoedipraja, "What binds public prosecutors, legal counsel and judges is their simultaneous orientation towards the law, what separates them is that law prosecutors act in the public interest, legal counsel for the subjective interests of the accused and the judge in this conflict must arrive at concrete decisions ". At the court hearing, the essential and fundamental aspects of proof are carried out, both carried out by the public prosecutor, the defendant and or with his legal counsel, as well as by the panel of judges

\section{CONCLUSION}

1) The strength of this expert's information is free and does not bind the judge to use it if the expert's information is contrary to the judge's belief. The judge is free to judge and is not bound by the information given by an expert. In this case, the judge still needs other evidence to get the truth that is material/true. Based on expert information delivered by experts at the trial and it turns out that the judge in deciding the defendant was sure of the information given by the expert. This can be seen from the influence of expert evidence on the freedom of judges in making decisions against defendants which can be seen in judges' considerations.

2) The role of expert information presented at the trial of the presidential election $17^{\text {th }}$ on April 2019, and has been tried $21^{\text {st }}$ in June 2019, with several experts, both the applicant, the respondent, and related parties. Each brings in experts or experts, experts or experts brought in among them are experts in state science, state administration experts, criminal law experts, and also Electronic
Transaction Information experts (ITE) brought in from Japan to provide information about a legal event that is being tried at the Constitutional Court, despite the examination of experts until late at night, even until 2:00 in the morning delivered by an expert who is considered important because the judge is not an expert in everything. Judges can experience problems that cannot be resolved based on their knowledge, in this case, the judge can also explore new knowledge explained by experts during the trial by listening to the testimony of experts from various sciences that may be new to the panel of judges.

\section{REFERENCES}

[1] Adami Chazawi, Hukum Pembuktian Tindak Pidana Korupsi, Almuni, Bandung, 2006

[2] Achmad Soemoedipradja, Pokok pokok Hukum Acara Pidana di Indonesia, Alumni, Bandung, 1984

[3] Andi Hamzah, Asas-asas Hukum Pidana, Rineka Cipta, Jakarta, 1991.

[4] --------------, KUHP dan KUHAP, Rineka Cipta Jakarta

[5] Alfitra,Hukum Pembuktian Dalam Beracara Pidana, Perdata dan Korupsi di Indonesia, RAS,2012

[6] Bambang Poernomo, Pokok-pokok Hukum Acara Pidana, Liberty, Yogyakarta, 1993

[7] H. Zainuddin Ali, Metode Penelitian Hukum, Sinar Grafika, Jakarta

[8] Martiman Prodjohamidjojo, Penerapan Pembuktian Terbalik Dalam Delik Korupsi, Mandar Maju, Bandung, 2001.

[9] Mohammad Taufik Makarao, dan Subasril, Hukum Acara Pidana, Ghalia Indonesia, Jakarta.

[10] Mr. S.M. Amin, Hukum Acara Pengadilan Negeri, Penerbit : Pradnja Paramita,

[11] Munir Fuady, Teori Hukum Pembuktian, PT. Citra Aditya Bakti, Bandung, 2006.

[12] Ridwan Halim, Hukum Pidana Dalam Tanya Jawab, Ghalia Indonesia, Jakarta, 986.

[13] P.A.F. Lamintang, Dasar-dasar Hukum Pidana Indonesia, Citra Aditya Bakti, Bandung, 1997.

[14] Wirjono Prodjodikoro, Hukum Acara Pidana di Indoensia, Sumur Bandung, Cetakan kedelapan, 1974.

[15] R. Tresna, Komentar H.I.R, Pradnya Paramita, Jakarta, 2000

[16] W.L.G. Lemaire, Dasar-Dasar Hukum Pidana Indonesia,

[17] Terj. P.A.F. Lamintang, PT. Citra Aditya Bakti, Bandung, 1997. Wirjono Prodjodikoro, Hukum Acara Pidana di Indonesia, Sumur Bandung, 1985.

[18] Yahya Harahap, Pembahasan Permasalahan dan Penerapan KUHAP, Pustaka Kartini, Jakarta, 1988.

[19] Undang-undang N0 30 tahun 1999 tentang Arbitrase

[20] SEMA No. 13 Tahun 2008, tentang pembuktian delik Pers. 